\title{
Storability of Onion Seeds as Influenced by Varieties, Date of Sowing and Storage Containers (Allium cepa L.)
}

\author{
K. Lokesh*, G. C. Shekar, B. S. Ganiger and A. S. Police Patil \\ University of Agricultural Sciences, Raichur-584102, Karnataka, India \\ *Corresponding author
}

\section{A B S T R A C T}

\begin{tabular}{l} 
Ke y w or d s \\
$\begin{array}{l}\text { Onion varieties, } \\
\text { different planting } \\
\text { dates and Storage } \\
\text { containers }\end{array}$ \\
Article Info \\
$\begin{array}{l}\text { Accepted: } \\
\text { 20 May 2020 } \\
\text { Available Online: } \\
\text { 10 June 2020 }\end{array}$ \\
\hline
\end{tabular}

\section{Keywords}

Onion varieties, different planting dates and Storage containers

Accepted:

20 May 2020

10 June 2020
An experiment was carried out on Storability of Onion seeds as influencedby varieties, date of sowing and storage containers (Allium cepaL.)one of the major limitations in onion cultivation in India is lack of good quality seed at the time of sowing production and make available quality seeds are of paramount importance to sustain onion production in the country. Onion is a poor storer, during storage period, per cent germination was highest in $10^{\text {th }}$ November produce crop. Among the varieties, ArkaNiketan recorded higher germination and it was lowest in ArkaBindu. During storage period percent germination, seedling length, vigour index, field emergence was highest in the seed stored in polythene bag and it was lowest in the seed stored in cloth bag. The electrical conductivity of seed leachate was found to increase over the storage period in all the dates of planting. Among the varieties, E.C. of seed leachate was highest in ArkaBindu and it was lowest in ArkaNiketan.

\section{Introduction}

Onion (Allium cepa L.) is an important vegetable and spice crop produced in all the regions of India. It is also an important foreign exchange earner for the country. Belongs to family Alliaceae.

In India, Maharashtra is the leading state for onion production accounting for more than 16 per cent of area and 25 per cent of production .The other major onion producing states are Gujarat, Karnataka, Uttar Pradesh,
Andra Pradesh and Orissa. The productivity was highest in Gujarat (20.18t/ha) followed by Maharashtra (19.20t/ha) and Haryana (14.86t/ha). The major onion producing belts in India are Bhavanagar and Rajkot in Gujarat state, Naaik and Pune in Maharashtra, Badun in Uttarpradesh, chitradurga and Bellary in Karnataka State.

The location specific research work is necessary to determine the optimum planting dates in any area where seed production 
practices are not standardized, one of the major limitations in onion cultivation in India is lack of good quality seed at the time of sowing. Initial seed quality, seed moisture, storage temperature and relative humidity and storage containers have been found to affect the longevity.

The time of production and interaction of genotypes also determine the quality of seed and storability as the crop produced at different times being exposed to varying environmental conditions especially during seed maturation stage . Justice and Bass(1979)opined that onion seeds loose the vigour and viability comparatively faster than seeds of other vegetables and failed to remain viable for more than one year under ambient conditions.

\section{Seed source}

Seeds of onion variety produced at Indian Institute of Horticulture Research. Hessaraghatta, Bengalure.

\section{Materials and Methods}

The study was conducted at Department of seed science \&Technology, college of agriculture, University of Agricultural sciences, Raichur. Seeds of short day onion varieties viz., ArkaBindu, ArkaPithamber and ArkaNiketan produced under different dates of planting viz., $10^{\text {th }}, 25^{\text {th }}$ November and $10^{\text {th }}$ and $25^{\text {th }}$ December were subjected for storage study.

Seeds with 7 percent moisture were treated with CARBONDIZIM @ $2 \mathrm{~g}$ per kg of seeds. Ten sub samples of onion seeds weighing $250 \mathrm{~g}$ of each treatment were drawn randomly .Five samples of each were packed in cloth bag and five samples of each treatment were packed in polythene bag of 700 gauge and heat sealed to avoid sampling error. The seeds were stored under ambient room conditions then the samples were drawn at bimonthly and tested for seed quality parameters viz., percent germination, Seedling length, vigour index and field emergence.

The germination was tested as per the procedure outlined by (Anon., 2010), seedling length and seedling vigour index was calculated as per the Abdul Baki and Anderson (1973).

\section{Results and Discussion}

The Seeds obtained from $25^{\text {th }}$ November crop showed better storability in terms of germination $(80.11 \%)$, seedling length $(11.44 \mathrm{~cm})$, vigour index(919) and field emergence $(44.05 \%)$ at 10 months of storage which is significantly superior to seeds produced from $10^{\text {th }}$ December and $25^{\text {th }}$ December while, $10^{\text {th }}$ November sown crop was on par with $25^{\text {th }}$ November crop.

Kanwar et al., (2000)have reported that seeds produced from late planting beyond middle of November adversely affected the seed quality under the Punjab conditions.

Among the varieties throughout the storage period ArkaNiketan recorded highest germination percentage( 92.95 to 77.91 )while, Arkabindu recorded the lowest germination percentage (90.87 to 74.25) Effect of containers the germination percentage differed significantly among the storage containers at all the intervals of testing.

Throughout the storage period seeds stored in polythene bag recorded the highest germination percentage (92.11) and it was lowest (91.72).the interactions due to date of planting and containers was significant for germination percentage at 2 month of storage .However, it did not differ significantly at initial 4,8 and 10 months of storage. The reduction in germination in later planting may 
be attributed to the reduction in test weight and unfavourable weather conditions that prevailed during seed development and maturation.

Similar variations in percent germination as influenced by sowing dates have been reported by Saini et al., (1980) Kanwar et al., (2000) reported that onion seeds produced from late planting adversely affected seed quality under Punjab conditions. The interaction due to date of planting and varieties and interaction due to varieties and containers did not differ significantly for germination percentage throughout storage period.

The seeds produced at different planting dates and varieties differed significantly for seedling length and vigour index during storage. It was highest in the early planted crop and continued to maintain their superiority consistently even at 6 months. at the beginning of storage the seedling length $(14.12 \mathrm{~cm})$ and vigour index(1333)were the highest in November planted crop and they were lowest $(13.26 \mathrm{~cm}, 1195$ respectively in $25^{\text {th }}$ December planted crop, the corresponding decrease in seedling length and vigour index were $10.80 \mathrm{~cm}$ and 751 respectively at the end of the storage period.

The difference in seedling length and vigour index may be attributed to difference in test weight and inherent varietal character. Singh et al., (1979)noticed that higher vigour index from $1^{\text {st }}$ November planting than late planting in onion. Storage containers influenced the seed quality in terms of seedling length and vigour index throughout the storage period. It was highest in polythene bag $(14.10 \mathrm{~cm})$ initially and continued to record highest in the storage period and decreased with prolonged storage period. the differences in seedling length and vigour index among the containers were also reported by Padma and Muralimohan Reddy(2000)who have observed that the large difference in the retention of seed quality of onion seed stored in different moisture impervious container at 7.15 percent and 5.3 percent seed moisture.

Similar observations in seed quality variation due to storage container have been reported by Jagadish et al., (1994)who have reported that the seed of onion cv.Pusa Red stored in polythene laminated pouch under ambient conditions(20.3 to $26 \mathrm{c}$ ).

Similarly, Doijode(1995)reported that storage of onion seed with silica gel in aluminium foil laminated pouches, glass or polyethylene bag as effective in retaining high seed germ inability upto 7 years without loss of seedling vigour.

Electrical conductivity of seed leachate differed significantly among the dates of planting the difference in E.C. among the dates of planting was due to the differences in the level of seed deterioration which is a consequences of differential levels of membrane degradation. Bhasker Reddy(1998)reported that parental seeds of Sunflower hybrids grown in early planting recorded less E.C. of seed leachate as compared to delayed plantings.

Seed stored in polythene bag recorded consistently and lower E.C. throughout the storage period as compared to seed stored in cloth bag. Bradnock and Mathews(1970) reported that weaker the membrane system larger could be the quantity of electrolytes leached out from seeds and greater the conductivity of steep water. Suresh et al., (2002) observed that fluctuation in moisture content of seed stored in cloth bag due to change in relative humidity of atmosphere. 
Table.1 Germination (\%) of onion varieties as influenced by date of planting and Containers at different months of storage

\begin{tabular}{|c|c|c|c|c|c|c|}
\hline \multirow[t]{2}{*}{ Treatment } & \multicolumn{6}{|c|}{ Month of Storage } \\
\hline & Initial & 2 & 4 & 6 & 8 & 10 \\
\hline \multicolumn{7}{|c|}{ A. Date of planting } \\
\hline $10^{\text {th }}$ November (D1) & 93.27 & 91.72 & 89.27 & 25.16 & 82.94 & 79.16 \\
\hline $25^{\text {th }}$ November (D2) & 93.66 & 91.44 & 90.61 & 85.94 & 85.00 & 80.11 \\
\hline $10^{\text {th }}$ December (D3) & 90.66 & 89.38 & 87.05 & 82.94 & 79.44 & 75.55 \\
\hline $25^{\text {th }}$ December (D4) & 90.55 & 87.05 & 83.94 & 78.50 & 73.22 & 68.22 \\
\hline S.Em \pm & 0.33 & 0.39 & 0.69 & 0.66 & 0.65 & 0.76 \\
\hline C.D. $(P=0.05)$ & 0.94 & 1.12 & 1.98 & 1.87 & 1.85 & 2.67 \\
\hline \multicolumn{7}{|l|}{ B. Varieties } \\
\hline V1 (ArkaBindu) & 90.87 & 88.54 & 86.00 & 81.16 & 79.12 & 74.25 \\
\hline V2 (ArkaPithamber) & 91.91 & 89.75 & 87.91 & 82.87 & 79.25 & 75.12 \\
\hline V3 (ArkaNiketan) & 92.95 & 91.42 & 89.25 & 85.37 & 82.08 & 77.91 \\
\hline S.Em \pm & 0.28 & 0.34 & 0.60 & 0.57 & 0.56 & 0.66 \\
\hline C.D. $(\mathbf{P}=\mathbf{0 . 0 5})$ & 0.82 & 0.97 & 1.72 & 1.62 & 1.60 & 1.87 \\
\hline \multicolumn{7}{|l|}{ C. Containers } \\
\hline C1 - Cloth bag & 91.72 & 89.50 & 86.36 & 81.69 & 78.75 & 73.44 \\
\hline $\begin{array}{c}\text { C2 - Polythene bag } \\
\text { (700 gauge) }\end{array}$ & 92.11 & 90.30 & 89.08 & 84.58 & 81.55 & 78.08 \\
\hline S.Em \pm & 0.23 & 0.28 & 0.49 & 0.46 & 0.46 & 0.54 \\
\hline C.D. $(P=0.05)$ & NS & 0.79 & 1.40 & 1.32 & 1.31 & 1.53 \\
\hline
\end{tabular}

NS-Non-significant

Table.2 Seedling length (\%) of onion varieties as influenced by date of planting and containers at different months of storage

\begin{tabular}{|c|c|c|c|c|c|c|}
\hline \multirow[t]{2}{*}{ Treatment } & \multicolumn{6}{|c|}{ Month of Storage } \\
\hline & Initial & 2 & 4 & 6 & 8 & 10 \\
\hline \multicolumn{7}{|c|}{ D. Date of planting } \\
\hline $10^{\text {th }}$ November (D1) & 14.12 & 13.92 & 13.91 & 13.51 & 12.27 & 10.56 \\
\hline $25^{\text {th }}$ November (D2) & 14.23 & 13.84 & 13.37 & 13.18 & 11.00 & 11.44 \\
\hline $10^{\text {th }}$ December (D3) & 13.37 & 12.99 & 12.67 & 12.31 & 12.23 & 11.28 \\
\hline $25^{\text {th }}$ December (D4) & 13.26 & 12.75 & 12.32 & 11.90 & 11.69 & 10.81 \\
\hline S.Em \pm & 0.14 & 0.15 & 0.14 & 0.13 & 0.15 & 0.35 \\
\hline C.D. $(\mathbf{P}=\mathbf{0 . 0 5})$ & 0.39 & 0.43 & 0.30 & 0.37 & 0.42 & NS \\
\hline \multicolumn{7}{|l|}{ E. Varieties } \\
\hline V1 (ArkaBindu) & 13.61 & 13.02 & 12.73 & 12.45 & 11.69 & 10.76 \\
\hline V2 (ArkaPithamber) & 13.51 & 13.33 & 13.06 & 12.66 & 12.06 & 10.73 \\
\hline V3 (ArkaNiketan) & 14.12 & 13.77 & 13.42 & 13.06 & 12.31 & 11.57 \\
\hline S.Em \pm & 1.12 & 0.13 & 0.12 & 0.11 & 0.13 & 0.30 \\
\hline C.D. $(\mathbf{P}=\mathbf{0 . 0 5})$ & 0.34 & 0.37 & 0.34 & 0.32 & 0.36 & NS \\
\hline \multicolumn{7}{|l|}{ F. Containers } \\
\hline C1 - Cloth bag & 13.48 & 12.95 & 12.56 & 12.35 & 11.75 & 10.38 \\
\hline $\begin{array}{c}\text { C2 - Polythene bag } \\
\text { (700 gauge) }\end{array}$ & 14.01 & 13.81 & 13.58 & 13.10 & 12.30 & 11.66 \\
\hline S.Em \pm & 0.09 & 0.10 & 0.09 & 0.09 & 0.10 & 0.25 \\
\hline C.D. $(\mathbf{P}=\mathbf{0 . 0 5})$ & 0.28 & 0.30 & 0.27 & 0.26 & 0.29 & 0.76 \\
\hline
\end{tabular}

NS-Non-significant 
Table.3 Vigour index germination $(\%)$ x seedling length $(\mathrm{cm})$ of onion varieties as influenced by date of planting and containers at different months of storage

\begin{tabular}{|c|c|c|c|c|c|c|}
\hline \multirow[t]{2}{*}{ Treatment } & \multicolumn{6}{|c|}{ Month of Storage } \\
\hline & Initial & 2 & 4 & 6 & 8 & 10 \\
\hline \multicolumn{7}{|c|}{ G. Date of planting } \\
\hline $10^{\text {th }}$ November $(\mathrm{D} 1)$ & 1317 & 1281 & 1225 & 1156 & 1109 & 888 \\
\hline $25^{\text {th }}$ November (D2) & 1333 & 1267 & 1212 & 1135 & 1011 & 919 \\
\hline $10^{\text {th }}$ December (D3) & 1235 & 1162 & 1103 & 1026 & 971 & 859 \\
\hline $25^{\text {th }}$ December (D4) & 1195 & 1111 & 1046 & 937 & 847 & 751 \\
\hline S.Em \pm & 14.31 & 15.88 & 14.53 & 11.65 & 10.37 & 18.02 \\
\hline C.D. $(\mathbf{P}=\mathbf{0 . 0 5})$ & 40.63 & 45.09 & 41.27 & 33.08 & 29.46 & 51.16 \\
\hline \multicolumn{7}{|l|}{ H. Varieties } \\
\hline V1 (ArkaBindu) & 1238 & 1155 & 1087 & 1018 & 918 & 806 \\
\hline V2 (ArkaPithamber) & 1248 & 1198 & 1157 & 1050 & 949 & 844 \\
\hline V3 (ArkaNiketan) & 1324 & 1263 & 1195 & 1122 & 1012 & 913 \\
\hline S.Em \pm & 12.39 & 13.75 & 12.59 & 10.09 & 8.98 & 15.60 \\
\hline C.D. $(\mathbf{P}=\mathbf{0 . 0 5})$ & 35.19 & 39.05 & 35.74 & 28.65 & 25.51 & 44.30 \\
\hline \multicolumn{7}{|l|}{ I. Containers } \\
\hline C1 - Cloth bag & 1237 & 1159 & 1086 & 1013 & 905 & 772 \\
\hline $\begin{array}{c}\text { C2 - Polythene bag } \\
\text { (700 gauge) }\end{array}$ & 1303 & 1251 & 1207 & 1113 & 1005 & 937 \\
\hline S.Em \pm & 10.12 & 11.23 & 10.28 & 8.23 & 7.33 & 12.74 \\
\hline C.D. $(P=0.05)$ & 28.73 & 31.88 & 29.18 & 23.39 & 20.83 & 36.17 \\
\hline
\end{tabular}

Table.4 Electrical conductivity (dsm-1) of onion varieties as influenced by date of planting and containers at different months of storage

\begin{tabular}{|c|c|c|c|c|c|c|}
\hline \multirow[t]{2}{*}{ Treatment } & \multicolumn{6}{|c|}{ Month of Storage } \\
\hline & Initial & 2 & 4 & 6 & 8 & 10 \\
\hline \multicolumn{7}{|c|}{ J. $\quad$ Date of planting } \\
\hline $10^{\text {th }}$ November (D1) & 1.85 & 195 & 2.10 & 2.27 & 2.44 & 2.63 \\
\hline $25^{\text {th }}$ November (D2) & 1.83 & 1.95 & 2.08 & 2.26 & 2.44 & 2.65 \\
\hline $1^{\text {th }}$ December (D3) & 2.00 & 2.11 & 2.25 & 2.43 & 2.62 & 2.82 \\
\hline $25^{\text {th }}$ December (D4) & 2.16 & 2.26 & 2.35 & 2.53 & 2.74 & 2.96 \\
\hline S.Em \pm & 0.01 & 0.01 & 0.01 & 0.01 & 0.01 & 0.02 \\
\hline C.D. $(P=0.05)$ & 0.03 & 0.03 & 0.04 & 0.04 & 0.05 & 0.06 \\
\hline \multicolumn{7}{|l|}{ K. Varieties } \\
\hline V1 (ArkaBindu) & 2.02 & 2.12 & 2.24 & 2.43 & 2.61 & 2.81 \\
\hline V2 (ArkaPithamber) & 1.96 & 2.08 & 2.19 & 2.37 & 2.58 & 2.78 \\
\hline V3 (ArkaNiketan) & 1.91 & 2.01 & 2.15 & 2.32 & 2.50 & 2.70 \\
\hline S.Em \pm & 0.09 & 0.09 & 0.01 & 0.01 & 0.01 & 0.02 \\
\hline C.D. $(P=0.05)$ & 0.02 & 0.02 & 0.03 & 0.03 & 0.04 & 0.05 \\
\hline \multicolumn{7}{|l|}{ L. Containers } \\
\hline C1 - Cloth bag & 1.98 & 2.11 & 2.26 & 2.44 & 2.64 & 2.84 \\
\hline $\begin{array}{c}\text { C2 - Polythene bag } \\
\text { (700 gauge) }\end{array}$ & 1.94 & 2.03 & 2.13 & 2.31 & 2.48 & 2.69 \\
\hline S.Em \pm & 0.07 & 0.07 & 0.01 & 0.01 & 0.01 & 0.01 \\
\hline C.D. $(P=0.05)$ & 0.02 & 0.02 & 0.03 & 0.03 & 0.03 & 0.04 \\
\hline
\end{tabular}


Seeds produced in $10^{\text {th }}$ and 25 November planted crop had higher germination, Seedling length, Vigour index and they continued to show consistently higher seed quality throughout the storage. However, seeds of onion could be stored for a period of 10 months maintaining above minimum germination percentage. Among the varieties ArkaNiketan had higher germination, field emergence and vigour index but the differences in seed quality parameters between the varieties were narrow. seeds of short day onion in November planted crop and stored in polythene bag had better storability.

\section{References}

Abdul-baki, A. A. and Anderson, J. D., 1973. Vigour determination in soybean seed by multiple criteria. Crop Sci., 10:31.34

Anonymous., 2010. International rules for Seed testing. Seed Sci \& Technol., 13: 299-513

Bhaskar Reddy, 1998. Influence of N-levels and planting dates on branching behaviour of CMS-234A and 234B of Sunflower (Helianthus annus L.) M.sc(Agri) thesis, University of Agril. Sciences, Dharwad.

Brandnock.,W.J. and Mathews,S.,1970, Assessing field and its relation to performance for Laboratory and field tests. Hort.Res., 10:50-58.

Doijode, S. D., 1995. Effect of silica gel and storage containers on seed viability and vigour in onion(Allium cepa, L)Seed Res.,23(2):67-70.

Jagadish, G. V., Prasanna, K. P. R. and Ranganathaiah,K.G., 1994, influence of storage conditions and containers on seed storability in onion(Allium Cepa,L.) Seed Tech News.,24(4):46

Justice, O. L. and Bass,1.N.,1979, Some practical information for storing and transporting seeds at ambient conditions .Principles and practices of seed storage .pp.174-182.London (Seed sci and Technol.,1988 pp.51)

Kanwar ,J.S.,Gill ,B.S. and Bal,S.S., 2000. Response of planting time and density to onion seed yield and quality. Seed Res., 28(2):212-214.

Padma, V. and Muralimohan Reddy.,2000. The effect of seed moisture and packaging material on onion seed longevity .Seed Res.,28(2):171-175.

Saini,S.K.,Singh ,J.N. and Gupta,P.C.,1980, Effect of planting date and variety on seed quality of soybean. Seed Res., 8(2):141-149.

Singh, D., Chakrabarthi, A. K., and Sinha, S. N. 1979. Produce quality seeds of vegetable crops., 10, Onion newsletter for the Tropics.2:31-33.

\section{How to cite this article:}

Lokesh. K., G. C. Shekar, B. S. Ganiger and Police Patil. A. S. 2020. Storability of Onion Seeds as Influenced by Varieties, Date of Sowing and Storage Containers (Allium cepa L.). Int.J.Curr.Microbiol.App.Sci. 9(06): 2650-2655. doi: https://doi.org/10.20546/ijcmas.2020.906.322 